\title{
Anatomical examination of the petiole of eupolypods I (Polypodiales)
}

\author{
JEANETTE MARA P. TAN ${ }^{1 \bullet}$, MARIA CELESTE BANATICLA-HILARIO ${ }^{2}$, PASTOR MALABRIGO ${ }^{3}$, \\ MARJORIE DELOS ANGELES ${ }^{1}$, INOCENCIO E. BUOT, JR. ${ }^{1}$ \\ ${ }^{1}$ Institute of Biological Sciences, College of Arts and Sciences, University of the Philippines Los Baños. College, Batong Malake, Laguna 4031, \\ Philippines. "email: jptan7@up.edu.ph \\ ${ }^{2}$ T.T. Chang Genetic Resources Center, International Rice Research Institute, Los Baños 4030, Laguna, Philippines \\ ${ }^{3}$ Department of Forest Biological Sciences, College of Forestry and Natural Resources, University of the Philippines Los Baños. College, Batong Malake, \\ Laguna 4031, Philippines
}

Manuscript received: 17 December 2019. Revision accepted: 2 April 2020.

\begin{abstract}
Tan JMP, Banaticla-Hilario MC, Malabrigo P, Angeles MD, JR Buot IE. 2020. Anatomical examination of the petiole of eupolypods I (Polypodiales). Biodiversitas 21: 1767-1777. The efficiency of petiole anatomy characters in identifying and describing the species and families of eupolypods I (Polypodiales) were explored. Specimens of 21 species, representing 13 genera and nine families were collected and processed in the laboratory, following proper dehydration and staining protocols. Transverse sections of the basal, median, and distal portions of the petiole were examined, photographed and analyzed. The results showed five taxonomically significant characters that can serve as family markers: (i) xylem shape, (ii) vascular bundle shape, (iii) number of vascular bundles, (iv) presence and absence of circumendodermal band, and (v) presence and absence of adaxial grooves. Based on these characters, a taxonomic key to the families of eupolypods I was constructed.
\end{abstract}

Keywords: Circumendodermal band, eupolypods I, petiole anatomy, vascular bundles

\section{INTRODUCTION}

The lack of taxonomic characters in describing fern taxa has been a problem by taxonomists and systematists (Christenhusz and Chase 2014). A particular example of this is the case of the families of eupolypods I which lack common characters due to vast morphological differences. And so, there is a need to explore the taxonomic utility of other characters such as petiole anatomy. Interestingly, petiole anatomy provides conserved and stable characters, particularly those of vascular bundles. The vascular architecture of petioles is relatively conserved and thus, can be considered as an effective approach to elucidate phylogeny of ferns (Hacke and Sperry 2001).

The significance of petiole anatomy was reflected in the promising results of the works of many authors. Lin and De Vol (1977), generated the key of ferns in Taiwan; Noraini et.al. (2014), discovered diagnostic anatomical characters for six Blechnum taxa; and Martinez and Vilte (2012), classified twelve Pteris species using vascular bundle and xylem shape. Another study by Hernandez-Hernandez et al. (2012) showed the different shapes of vascular bundles of the 89 fern species correlating with the presence of circumendodermal band.

Thus, this present work explores the use of petiole anatomy, as a tool in species identification and description of ferns, especially when sori are unavailable. The objectives of this study were to describe the petiole anatomy characters of selected eupolypods I species and to construct a dichotomous key to families of eupolypods I.

\section{MATERIALS AND METHODS}

\section{Selection of species and specimen collection}

The specimens examined for petiole anatomy were collected from various sites including Mt. Makiling in Los Baños, Laguna, Quezon-Laguna UP Land Grant in Pakil, Laguna, and Mt. Mantalingahan in Puerto Princesa, Palawan. A total of twenty-one (21) species were collected. The selected species per family were based on the type genus or the nearest species to the type genus of each family, following PPG I. Fresh specimens were prepared from three species per family collected from the field. Didymochlanaceae had only one species and incidentally, no specimen was collected during fieldwork. Resources and options available were already exhausted in the collection of the representative specimens in this study.

Specimens were identified using the Copeland's Fern Flora of the Philippines (1958), Pteridophytes of Mt. Makiling and Vicinity by Price (1975), and Flora Malesiana: Fern and Fern Allies by Hovenkamp (1998). The voucher specimens were identified, pressed and deposited in the Plant Biology Division Herbarium, Institute of Biological Science, University of the Philippines Los Baños, Laguna.

\section{Petiole examination}

Anatomical examination and measurements were made using petioles fixed in formalin-acetic acid alcohol (FAA) solution for a week. FAA-A solution was composed of formalin $(12 \%)$ and $95 \%$ ethanol $(88 \%)$, while FAA-B solution was composed of acetic acid (10\%) and distilled water $(90 \%)$ mixed together in a 1: 1 ratio (Johansen 1940). The free-hand technique was used to obtain transverse sections of the petiole at the basal (next to the rhizome), middle (half of the petiole) 

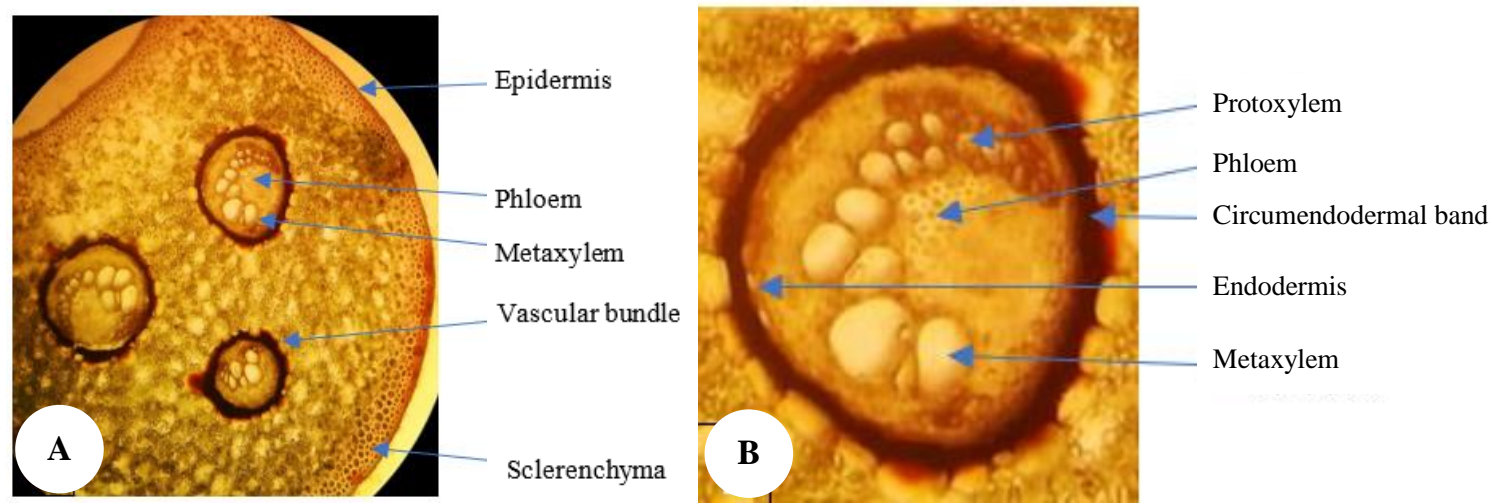

Figure 1. Cross-section of Nephrolepis biserrata petiole (A) (100x magnification), zoom in image of vascular bundle (B)

\section{Permanent slide preparation}

Cross-sections were done using the free-hand sectioning technique. All sections were cut using a new Gillette razor blade. Very thin sections were cut and transferred to a petri dish with water to prevent cell dehydration. The sections were stained with Safranin-Fast Green and dehydrated in series of 5\% ETOH, 10\% ETOH, 20\% ETOH, 30\% ETOH, 50\% ETOH, stained with Safranin O, 50\% ETOH, 70\% ETOH, 85\% ETOH, 95\% ETOH, 1: 1: 1 of xylene, aniline, and $95 \%$ ETOH, 2: 1 of xylene and aniline, $3: 1$ of xylene and aniline, pure xylene and then mounted on Canada Balsam (Berlyn and Mikshe 1976; Chamberlain 1932). Permanent slides were deposited at the Plant Biology Division Herbarium, Institute of Biological Sciences, University of the Philippines, Los Baños, Laguna.

\section{Microscopy}

Observations, illustrations, and photographs of the sections were done using Olympus CX21 light compound microscope (10x-100x). Hand illustrations were done based on the photographs, and scales of each section were processed through an ImageJ software, where it calculates the area and pixel value of the photo, generating scales.

\section{RESULTS AND DISCUSSION}

\section{General petiole anatomy characters of selected species of eupolypods I}

The results showed a diversity of interesting anatomical characters (Table 1). All 21 species exhibited a dictyostelic stelar structure which appears to have dissected stele and many leaf gaps. This conforms to the claim of Hacke and Sperry (2001) that eupolypods I species were able to conserve the dictyostelic vascular architecture in petioles. There were only one species (Davallia hymenophylloides), exhibiting a protostelic structure that appears to have central xylem surrounded by phloem and endodermis. This conforms with the results of Noraini et al. (2012). Table 1 implied that selected eupolypods I species share the same average three large vascular bundles with two or smaller bundles except for Hypodematium crenatum with only two vascular bundles, congruent with the results of PPG I (2016). Thus, eupolypods I species can be recognized through its stelar structure-a dictyostele, and the number of vascular bundles, usually two large ones on the adaxial portion and one large vascular bundle on the abaxial portion with smaller bundles on the side.

Much of the species $(86 \%)$ have circumendodermal band (CB), including species under the families Davalliaceae, Polypodiaceae, Oleandraceae, Nephrolepidaceae, Tectariaceae, Dryopteridaceae (except Polystichum horizontale), and Lomariopsidaceae. Previously, this was known as sclerenchymatic band, referring to group of cells with a distinctive color (even in the absence of stain) that ensheaths both vascular bundles and endodermis (Hernandez-Hernandez et al. 2009). Russow (1872), mentioned that this band seems to arise from the parenchyma cells and protects the phloem. It is adjacent to the endodermis, hence the term 'circumendodermal band'. Given the position of the CB, it has two possible purposes: [i] a protective function from the destruction of microorganisms, drying of protoplasm, and other pathogens; and [ii] biochemical functions such as resistance to bending and shear stresses (HernandezHernandez et al. 2012).

The species having CB are members of the families considered derived by Testo and Sundue (2016), namely, Dryopteridaceae, Lomariopsidaceae, Nephrolepidaceae, Tectariaceae, Oleandraceae, Davalliaceae, and Polypodiaceae. The results conformed to the study of Hernandez-Hernandez et al. (2012), where several eupolypods I families possess CB. Moreover, parallel to the current results, presence of CB was reported for Oleandra and Nephrolepis (Sen and Sen 1973), Davallia (Lin and DeVol 1977), and Tectaria (Velasquez 1983). Indeed, petiole anatomy can be an efficient taxonomic tool in distinguishing the genera and families of eupolypods I. 
Table 1. Detailed petiole anatomy characteristics of selected Eupolypods I species

\begin{tabular}{|c|c|c|c|c|c|c|c|c|c|c|c|c|c|}
\hline \multirow[t]{2}{*}{$\begin{array}{l}\text { Family/ } \\
\text { Species }\end{array}$} & \multicolumn{3}{|c|}{ Type of stele } & \multicolumn{3}{|c|}{$\begin{array}{c}\text { Shape of } \\
\text { xylem strand }\end{array}$} & \multicolumn{3}{|c|}{$\begin{array}{c}\text { Shape of } \\
\text { vascular bundles }\end{array}$} & \multirow{2}{*}{$\begin{array}{c}\begin{array}{c}\text { Number } \\
\text { of VB }\end{array} \\
\text { B M D }\end{array}$} & \multirow{2}{*}{\multicolumn{2}{|c|}{ 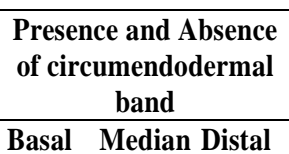 }} & \multirow{2}{*}{\begin{tabular}{|c|}
$\begin{array}{c}\text { Presence and } \\
\text { Absence of adaxial } \\
\text { grooves }\end{array}$ \\
Basal
\end{tabular}} \\
\hline & Basal & Median & Distal & Basal & Median & Distal & Basal & Median & Distal & & & & \\
\hline
\end{tabular}

Davalliaceae

Davallia hymenophylloides (Blume) Kuhn

Davallia solida (Forst.) Sw.

Davallia repens Khun

Protostele Protostele Protostele V shaped V shaped V shaped U shaped U shaped U shaped 3111 Present Present Present Absent Present Present

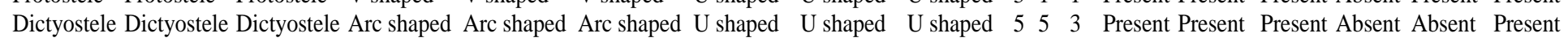
Dictyostele Dictyostele Dictyostele Arc shaped Arc shaped Arc shaped U shaped U shaped U shaped 5557 Present Present Present Absent Absent Absent

Didymochlaenaceae

Didymochlaena truncatula (Sw.) J.Sm.

\section{Dryopteridaceae}

Bolbitis heteroclita (Pr.) Ching in C. Chr.

Polystichum horizontale C. Presl

Arachniodes amabilis (Blume) Tindale

Hypodematiaceae

Hypodematium crenatum Kuhn \& Decken Dictyostele Dictyostele Dictyostele Arc shaped Arc shaped Arc shaped V shaped V shaped V shaped 222 Absent Absent Absent Absent Absent Absent

Lomariopsidaceae

Lomariopsis lineata (Presl.) Holttum

Lomariopsis kingii (Copel.) Holttum

Cyclopeltis crenata (Fee) C. Chr.

Nephrolepidaceae

Nephrolepis cordifolia (L.) C. Presl

Nephrolepis biserrata (Sw.) Schott

Nephrolepis falcata (Cav.) C. Chr.

Dictyostele Dictyostele Dictyostele Arc shaped Arc shaped Arc shaped Semi-circle Semi-circle Semi-circle 333 Absent Absent Absent Absent Absent Absent

Polypodiaceae

Microsorium heterocarpum (Blume) Ching Dictyostele Dictyostele Dictyostele C shaped $\quad$ C shaped $\quad$ C shaped U shaped U shaped U shaped $344 \quad 4 \quad$ Present Present Present Absent Absent Absent $\begin{array}{lllllll}\text { Microsorium punctatum (L.) Copel. } & \text { Dictyostele Dictyostele Dictyostele C shaped } & \text { C shaped } & \text { C shaped U shaped U shaped U shaped } 344 & 4 & \text { Present Present Present Absent Absent Absent }\end{array}$ Phymatosorus scolopendria (Burm.f.)Pic.Serm Dictyostele Dictyostele Dictyostele C shaped C shaped C shaped U shaped U shaped Ushaped 444 Present Present Present Absent Absent Absent Tectariaceae

Tectaria angulata (Willd.) Copel Tectaria dissecta (G. Forst.) Lellinger Tectaria hilocarpa (Fee) M.G. Price

Dictyostele Dictyostele Dictyostele Hook shaped Hook shaped Hook shaped V shaped V shaped V shaped 5517 Present Present Present Present Present Present

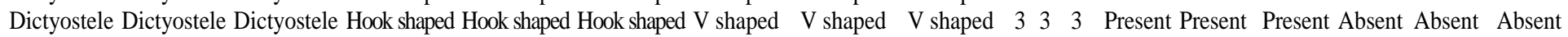
Dictyostele Dictyostele Dictyostele Hook shaped Hook shaped Hook shaped U shaped U shaped U shaped $25 \quad 5 \quad 5$ Present Present Present Absent Absent Absent

Oleandraceae

Oleandra maquilingensis Copel. 
Meanwhile, $14 \%$ of the species did not possess circumendodermal band, including Hypodematium crenatum (Hypodematiaceae), Polystichum horizontale (Dryopteridaceae) and Didymochlaena truncatula (Didymochlaenaceae). These species are terrestrial and creeping in habit compared to those species with $\mathrm{CB}$ which are mostly epiphytic or lithophytic. The presence of $\mathrm{CB}$ in epiphytic or lithophytic species have been proposed to increase the structural rigidity of the frond, an important feature of these species. In many epiphytes and lithophytic species, fronds are exposed at steep angles and susceptible to damage by falling debris from the canopy (Hacke and Sperry 2001). The difference in the cell wall thickness of the $\mathrm{CB}$, varies among species and may be useful for fern systematics. The study of Hernandez-Hernandez et al., (2012), showed that there were various degrees of thickness on CB exhibited in some genera of eupolypods I. In fact, in their study, there was high interspecific differentiation in the ten species of Elaphoglossum and Polypodium. Thus, it is noteworthy for future studies to further understand the significance of $\mathrm{CB}$ in systematics at the species level.

It was also observed that all the species examined exhibited multiple leaf traces. Leaf traces are expansions from the vascular system in petiole towards the fronds (Evert 2006). It is composed of protoxylem, metaxylem, protophloem, and metaphloem that usually consist of transfer cells, which are important for the transport of substances between leaves and stem (Beck 2010). This confirms that most eupolypods I species can be characterized by the presence of multiple leaf traces except for the genus Hypodematium, which had a double leaf trace, as mentioned by Schuettpelz and Pryer (2008) and Hernandez-Hernandez et al. (2012).

The occurrence of the circumendodermal band correlates with a larger number of vascular strands in the leaf trace (Hernandez-Hernandez et al. 2012). Therefore, it can be deduced that most eupolypods I species have circumendodermal bands and multiple leaf traces which are anatomical characteristics defining this clade.

\section{Comparative stelar anatomy along the length of the petiole of eupolypods I}

Five different shapes of the xylem were observed. Seven species from families Davalliaceae, Dryopteridaceae, Hypodematiaceae, and Oleandraceae exhibited arc-shaped xylem (Figure 2), six species from families Nephrolepidaceae and Polypodiaceae with Cshaped xylem (Figure 3), three species from family Lomariopsidaceae with S-shaped xylem (Figure 4), two species from Tectariaceae with hook-shaped xylem (Figure 5) and one species Davallia hymenophylloides from Davalliaceae with V-shaped xylem (Figure 6).

Based on the results, there were also variations in stelar anatomy along the length of the petiole (Figures 7-13). It was observed that most of the species retained the arrangement of vascular bundles from the base to the tip. However, some species have various shapes of vascular bundles from the base and then fused to the adaxial part like that of Davallia hymenophylloides (Figure 7), Hypodematium crenatum (Figure 9), and Lomariopsis lineata (Figure 10). It was also observed that the distal region of the petiole of some species such as Davallia repens (Figure 7.I), Microsorum heterocarpum (Figure 12.C), Phymatosorus scolopendria (Figure 12.I), and $T$. angulata (Figure 13.C) had leaf traces.

Most of the species (Table 1) exhibited at least two large vascular bundles at the adaxial portion with two or smaller vascular bundles at the abaxial portion of the petiole, which is a common characteristic of dictyosteles (Hacke and Sperry 2001) (Figures 7-14). Adaxial grooves are furrows that can be seen in vascular bundles and on the petiole. Also, adaxial grooves are a significant character in ferns as it is used by numerous authors to describe and delineate taxa (Stockey et al. 1999; Kramer 1990; Regalado et al. 2018). From the transverse sections, grooves were most likely seen in the median and distal region of the petiole (Figures 7.C-F; 9.B-C; 11.H-I). Same observations were made for the adaxial grooves on the external petiole (Figures 7 E-F; 8.B, C, F, H, I; 10.I, 11.E, F, H, I; 13.C). The variations in arrangement and number of vascular bundles, the presence and absence of $\mathrm{CB}$, and the presence and absence of adaxial grooves, are diagnostic anatomical characters found in this study. These different anatomical characters mentioned in the study were found similar to the results of Hernandez-Hernandez et al. (2012), Ogura (1972), and Noraini et al. (2012, 2014). Hand illustrations of the vascular bundles of eupolypods I are found in Figures 7-13.

The species under Davalliaceae (D. hymenophylloides, $D$. solida, and $D$. repens) shared the same presence and thickness of the circumendodermal band (1/2), and Ushaped vascular bundles (Figure 7). The former, on the other hand, has a V-shaped xylem strand, unlike the latter two exhibiting arc-shaped xylem strands which form vascular bundles with two large adaxial and one large abaxial with two smaller bundles. The characters described provides additional species differentiation and identification in Davalliaceae species to the previous studies done by Noraini et al. (2012). Also, the results conform to the study of Kato and Mitsuta (1980), Kramer (1990), and Noraini et al. (2012).

The family Didymochlaenaceae consists of only one species, Didymochlaena truncatula. It had at least three semi-circle vascular bundles. On the other hand, Bolbitis heteroclita, Polystichum horizontale, and Arachniodes amabilis under Dryopteridaceae (Figure 8), have similar arc-shaped xylem with three to four vascular bundles. The vascular bundles were distributed into two large ones on the adaxial and one on the abaxial side, parallel to the study of Kramer (1990). The species Hypodematium crenatum from Hypodematiaceae (Figure 9), showed an arc-shaped xylem strand, V-shaped vascular bundles, two vascular bundles without circumendodermal band and adaxial grooves.

The taxonomic position of the genera Hypodematium is still unclear. It has been included in Athyriaceae (Wang et al. 2014), Thelypteridaceae (Ching 1963), Dryopteridaceae 
(Tyron and Tyron 1982, Kramer and Green 1990), and its own family Hypodematiaceae (PPG I).

The species under Lomariopsidaceae, (L. lineata, $L$. kingii, and Cyclopeltis crenata) (Figure 10), shared the same S-shaped xylem strand and U-shaped vascular bundles. Nephrolepis cordifolia, $N$. biserrata, and $N$. falcata from Nephrolepidaceae (Figure 11), showed similar C-shaped xylem strand and V-shaped vascular bundles. Microsorum heterocarpum, M. punctatum, and Phymatosorus scolopendria under Polypodiaceae (Figure 12) have similar patterns, exhibiting C-shaped xylem strand, U-shaped vascular bundles, presence of circumendodermal band (3/4) and absence of adaxial grooves. The $\mathrm{C}$-shaped vascular bundle character of both Nephrolepidaceae and Polypodiaceae has been reported before by Kramer (1990). This strengthens the relationship of Nephrolepidaceae and Polypodiaceae as possible sister families, as reported before by Kuo et al. (2011), Lehtonen (2011), and Liu et al. (2013).

Moreover, Tectaria angulata, T. dissecta, and $T$. repens, under Tectariaceae (Figure 13), have unique hookshaped xylem strand similar to the study of Patil et al. (2019). Also, it was observed that it has $1 / 4$ thick circumendodermal band and many vascular bundles coinciding with the study of Hernandez-Hernandez et al. (2012). Tectariaceae is morphologically diverse and challenging in terms of recognizing species. Thus, these distinct petiole anatomical characters observed from the study provided possible diagnostic characters for this family.
Oleandra maquilingensis under Oleandraceae (Figure 9) showed arc-shaped xylem strand and V-shaped vascular bundles; similar results to that of Kramer (1990). Oleandraceae have been previously associated with or included in Davalliaceae, Dryopteridaceae, and Nephrolepidaceae (Copeland 1940; Sen and Sen 1973). However, the results proved that Oleandraceae is independent to the three families as it showed different petiole anatomical features to the rest of its said affinities.

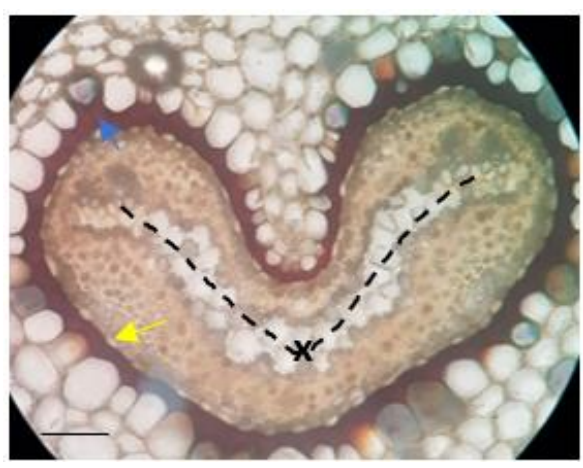

Figure 6. Transverse sections of Davallia hymenophylloides petiole specimens having $\mathrm{V}$-shaped xylem (imaginary line) obtained from the middle region of the petiole (x-xylem, yellow arrow-endodermis, blue arrow-circumendodermal band). Bar 100 $\mu \mathrm{m}(100 \mathrm{x})$
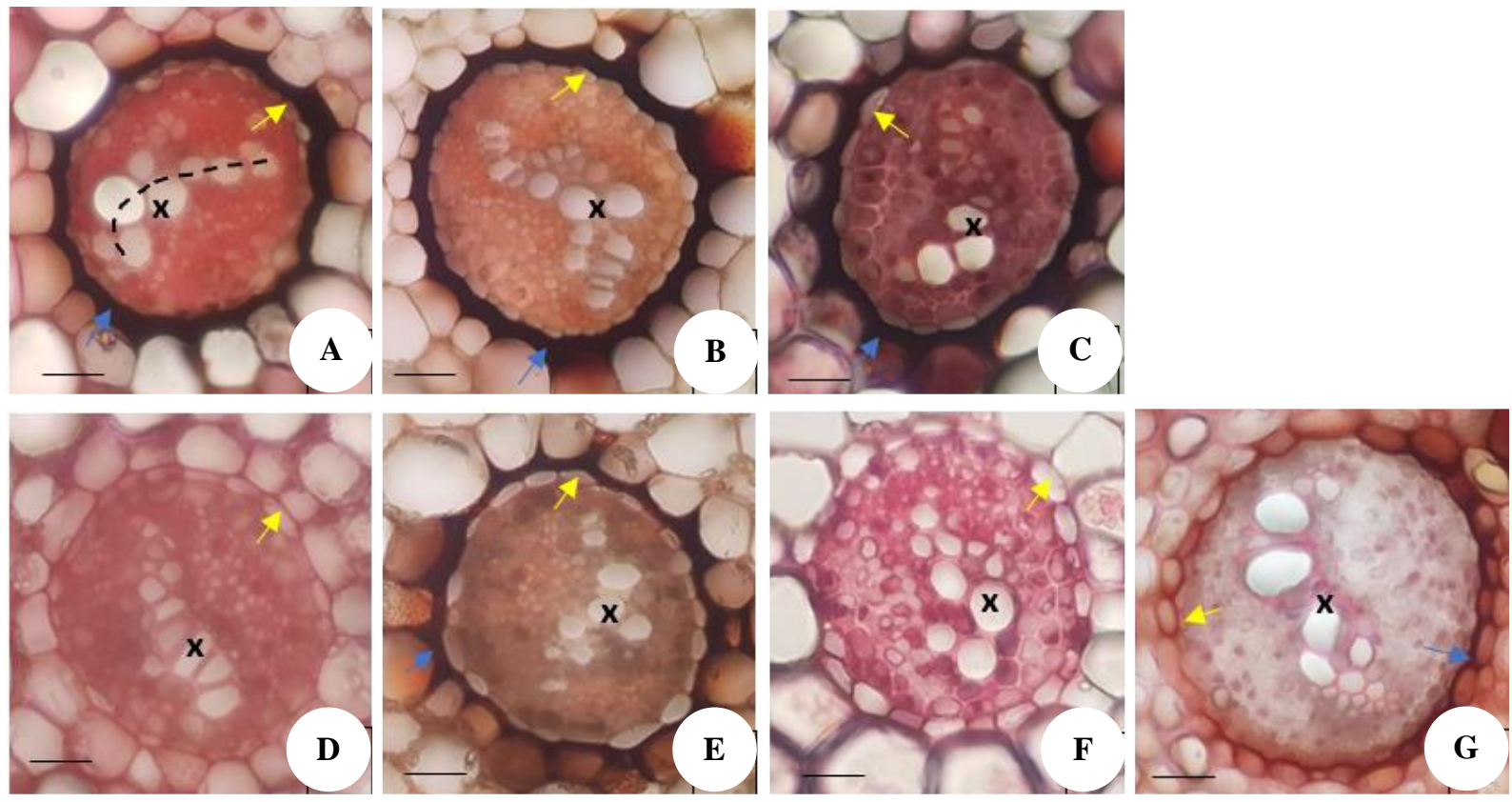

Figure 2. Transverse sections of eupolypods I petiole specimens having arc-shaped xylem (imaginary line) obtained from the middle region of the petiole. A. Davallia solida, B. Davallia repens, C. Bolbitis heteroclita, D. Polystichum horizontale, E. Arachniodes amabilis, F. Hypodematium crenatum, G. Oleandra maquilingensis. (x-xylem, yellow arrow-endodermis, blue arrow-circumendodermal band). 

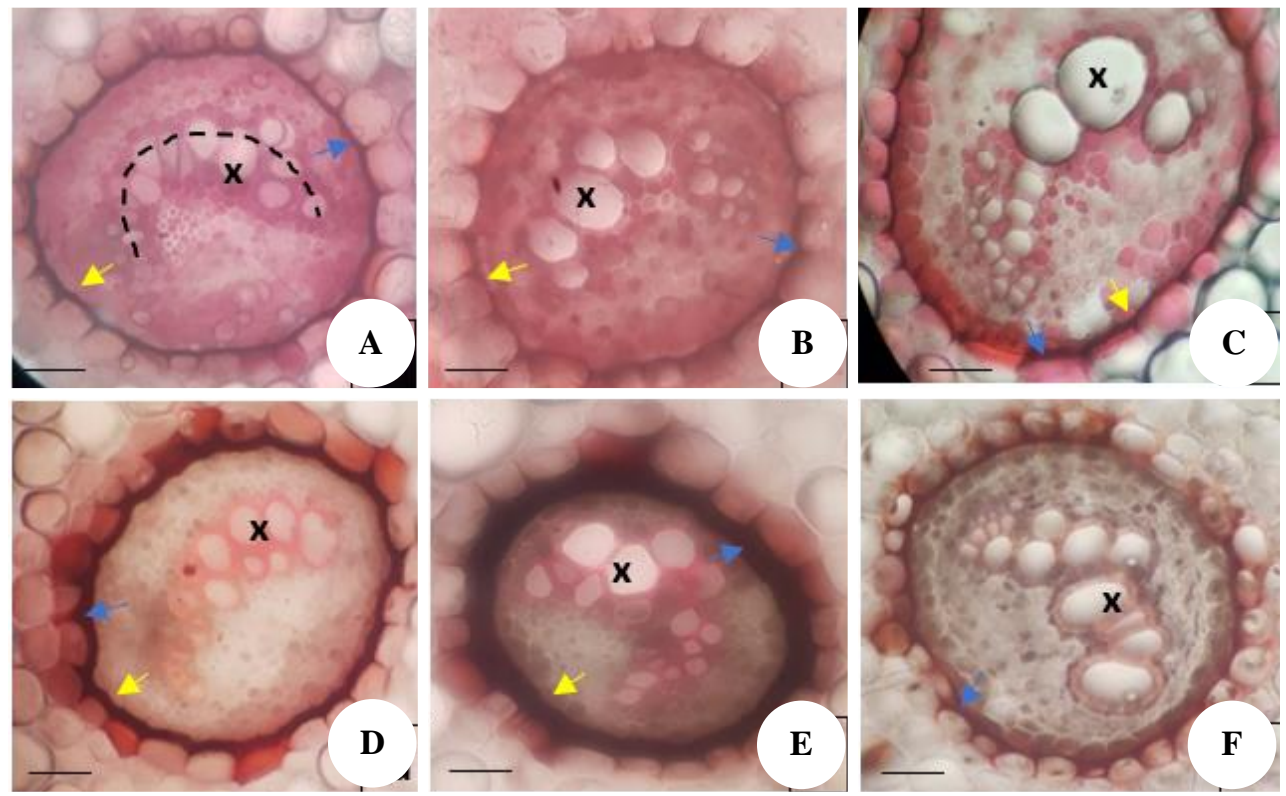

Figure 3. Transverse sections of eupolypods I petiole specimens having C-shaped xylem (imaginary line) obtained from the middle region. A. Nephrolepis cordifolia, B. Nephrolepis biserrata, C. Nephrolepis falcata, D. Microsorum heterocarpum, E. Microsorum punctatum, F. Phymatosorus scolopendria (x-xylem, yellow arrow-endodermis, blue arrow-circumendodermal band). Bars A-F: $100 \mu \mathrm{m}$ $(100 x)$
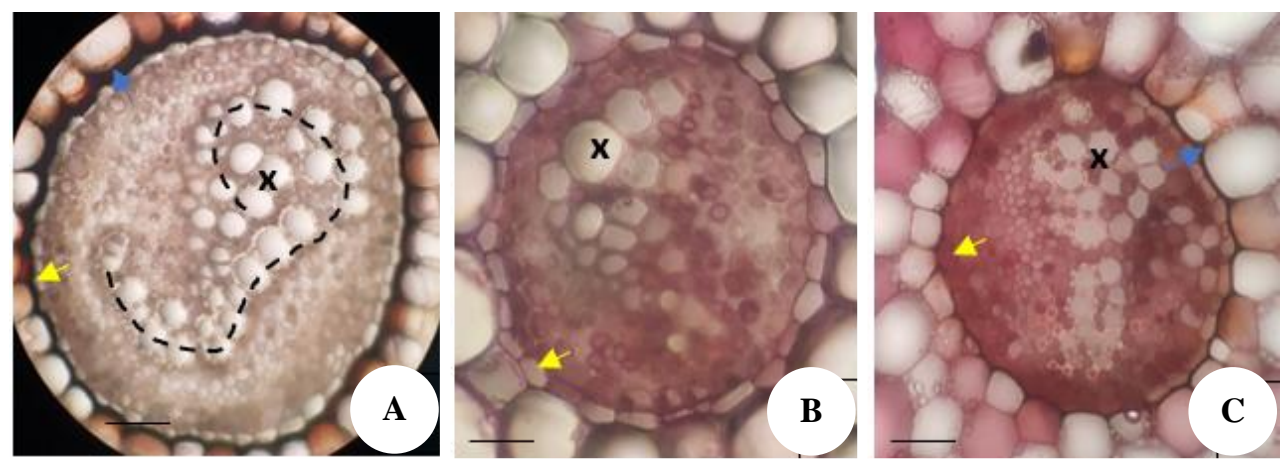

Figure 4. Transverse sections of eupolypods I petiole specimens having hook-shaped xylem (imaginary line) obtained rom the middle region of the petiole. A. Tectaria angulata; B. Tectaria dissecta, C. Tectaria hilocarpa (x-xylem, yellow arrow-endoder nis, blue arrowcircumendodermal band). Bars. A-C: $100 \mu \mathrm{m}(100 \mathrm{x})$
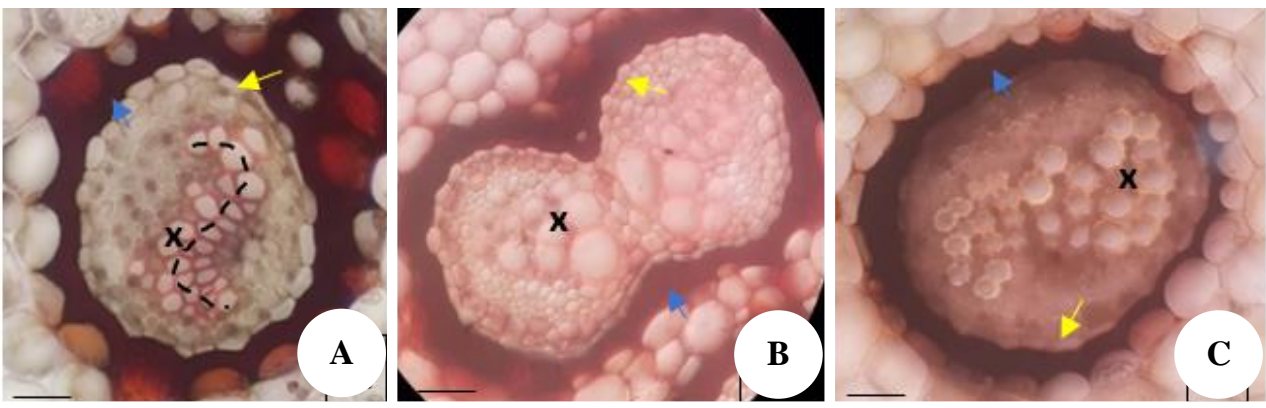

Figure 5. Transverse sections of eupolypods I petiole specimens having S-shaped xylem (imaginary line) obtained from the middle region of the petiole.A. Cyclopeltis crenata; B. Lomariopsis lineata, C. Lomariopsis kingii (x-xylem, yellow arrow-endodermis, blue arrow-circumendodermal band). Bars A-C: $100 \mu \mathrm{m}(100 \mathrm{x})$ 

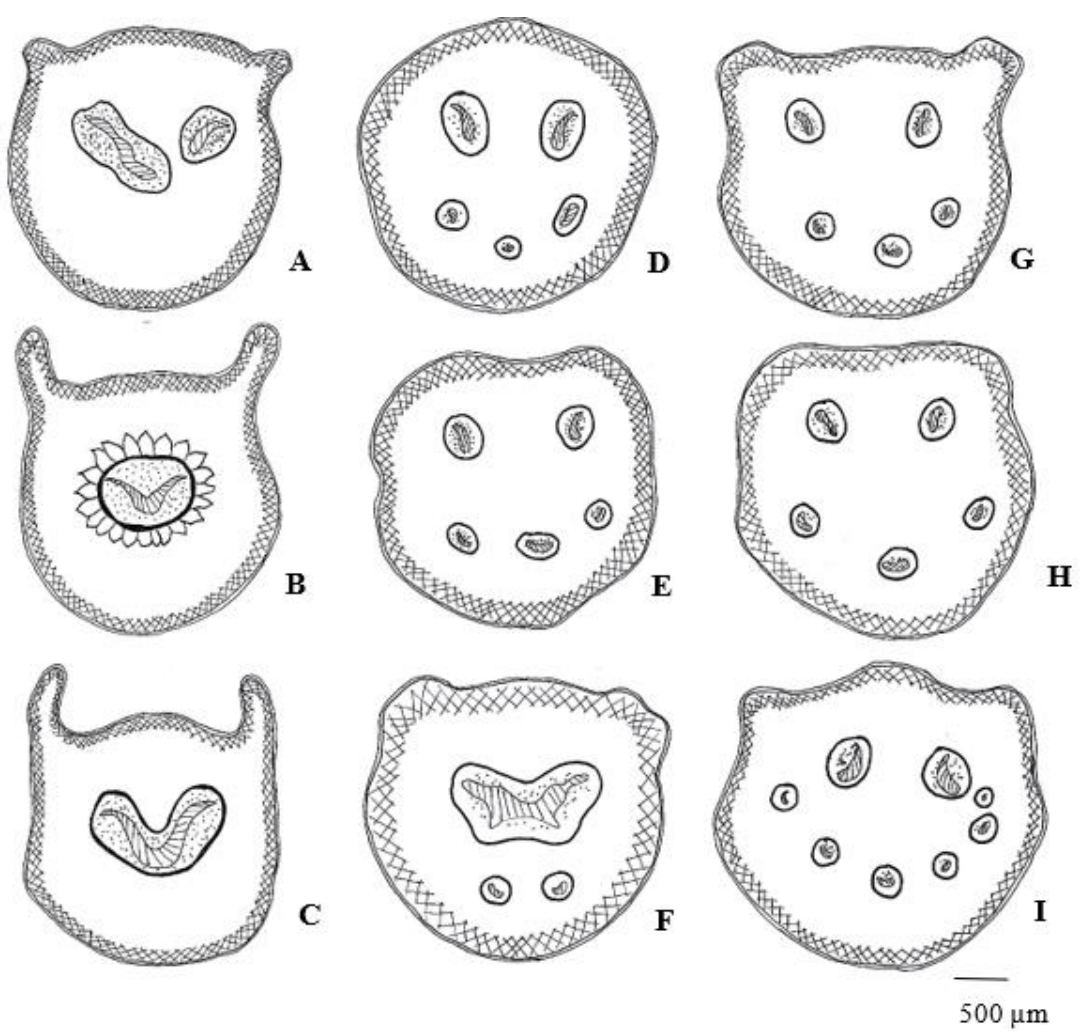

Figure 7. Hand illustrations of the cross-sections of Davalliaceae petiole showing the vascular bundle arrangement along the petiole: A, B, C. D. hymenophylloides, D, E, F. D. solida; G, H, I. D. repens. Basal section, close to the rhizome. A, D, G. Middle section of petioles. B, E, H. Upper section, near the blade. C, F, I. grid $=$ sclerenchyma, thick line $=$ endodermis + pericycle, dotted $=$ phloem, parallel lines $=$ xylem. Bars. A-I $500 \mu \mathrm{m}(40 \mathrm{x})$

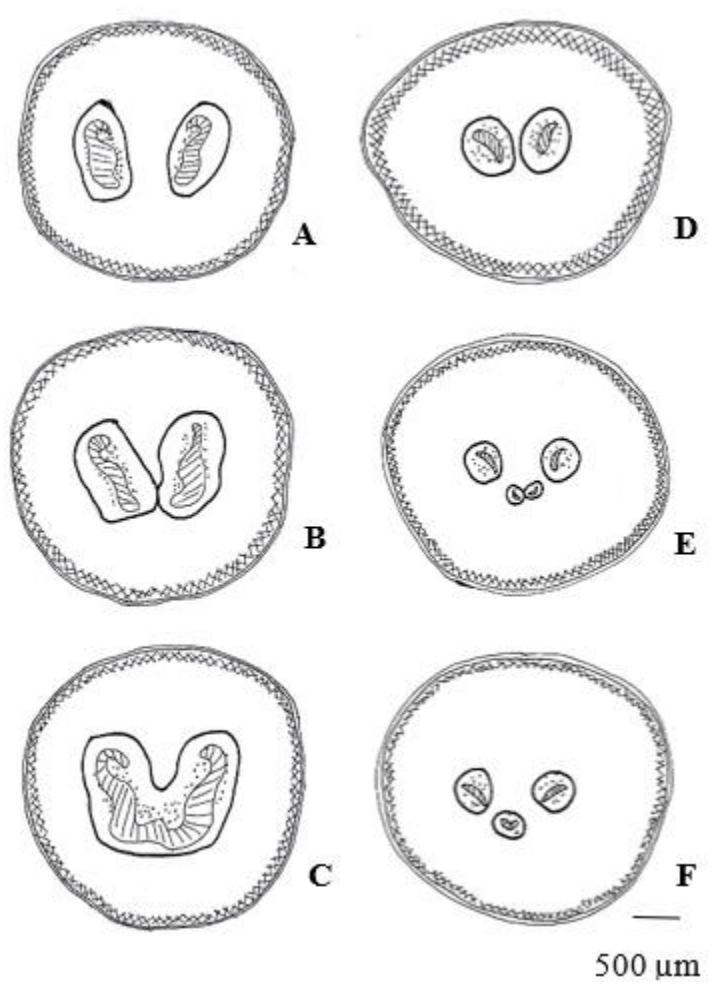

Figure 8. Hand illustrations of the cross-sections of Hypodematiaceae and Oleandraceae petiole cross-sections showing the vascular bundle arrangement along the petiole: A, B, C. Hypodematium crenatum (Hypodematiaceae) D, E, F. Oleandra maquilingensis (Oleandraceae). Basal section, close to the rhizome. A, D. Middle section of petioles. B, E. Upper section, near the blade. $\mathbf{C}, \mathbf{F}$. grid = sclerenchyma, thick line $=$ endodermis + pericycle, dotted $=$ phloem, parallel lines $=$ xylem. Bars. A-F 500 $\mu \mathrm{m}(40 \mathrm{x})$ 


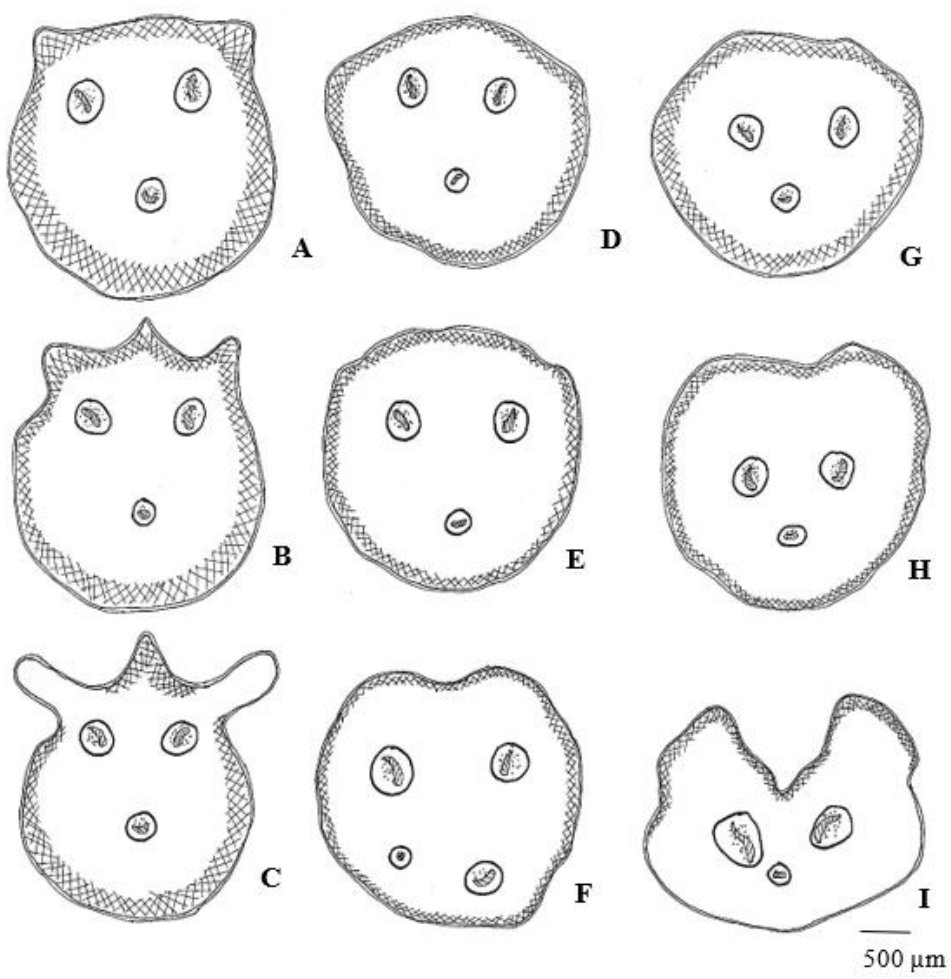

Figure 9. Hand illustrations of the cross-sections of Dryopteridaceae petiole cross-sections showing the vascular bundle arrangement along the petiole: A, B, C. Bolbitis heteroclita, D, E, F. Polystichum horizontale; G, H, I. Arachniodes amabilis. Basal section, close to the rhizome. A, D, G. Middle section of petioles. B, E, H. Upper section, near the blade. $\mathbf{C}, \mathbf{F}$, I. grid = sclerenchyma, thick line = endodermis + pericycle, dotted $=$ phloem, parallel lines $=$ xylem. Bars. A-I $500 \mu \mathrm{m}(40 \mathrm{x})$
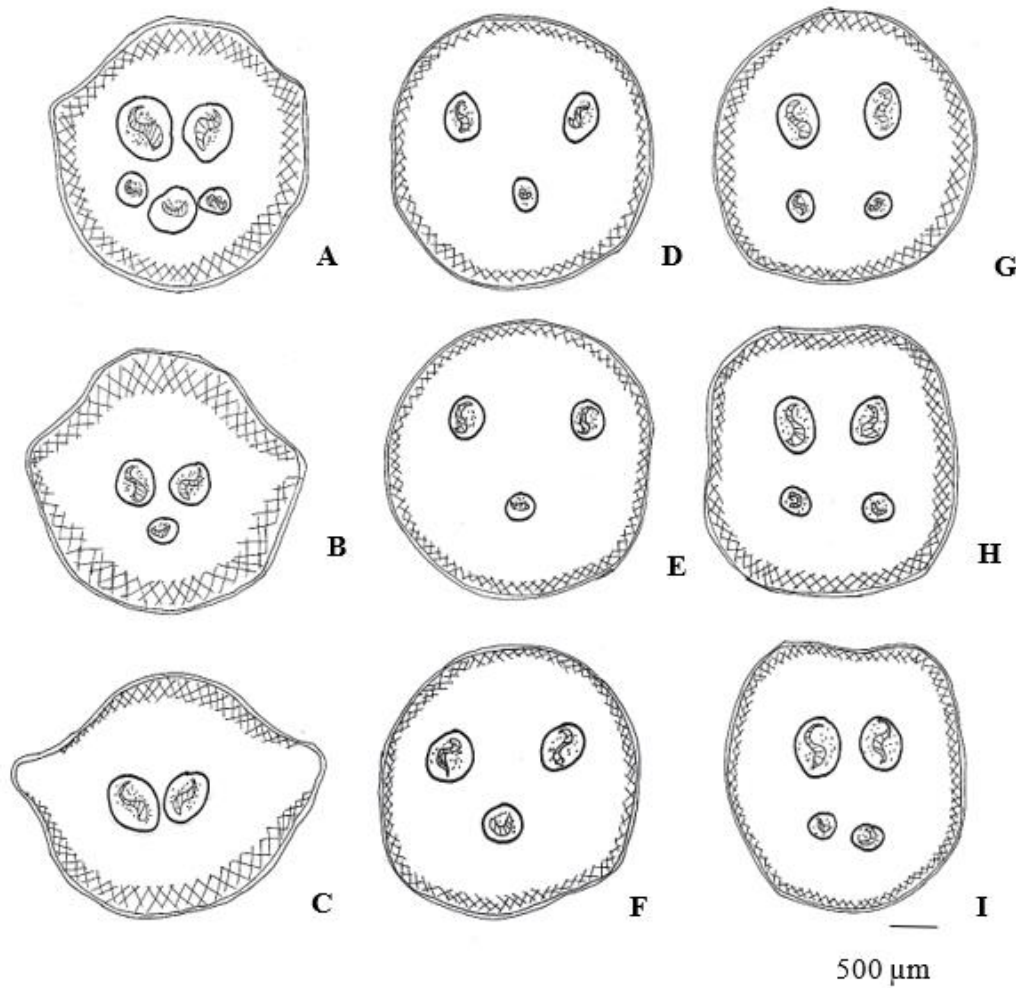

Figure 10. Hand illustrations of the cross-sections of Lomariopsidaceae petiole cross-sections showing the vascular bundle arrangement along the petiole: A, B, C. Lomariopsis lineata, D, E, F. Lomariopsis kingii; G, H, I. Cyclopeltis crenata. Basal section, close to the rhizome. A, D, G. Middle section of petioles. B, E, H. Upper section, near the blade. $\mathbf{C}$, F, I. grid = sclerenchyma, thick line = endodermis + pericycle, dot ted $=$ phloem, parallel lines $=$ xylem. Bars. A-I $500 \mu \mathrm{m}(40 \mathrm{x})$ 


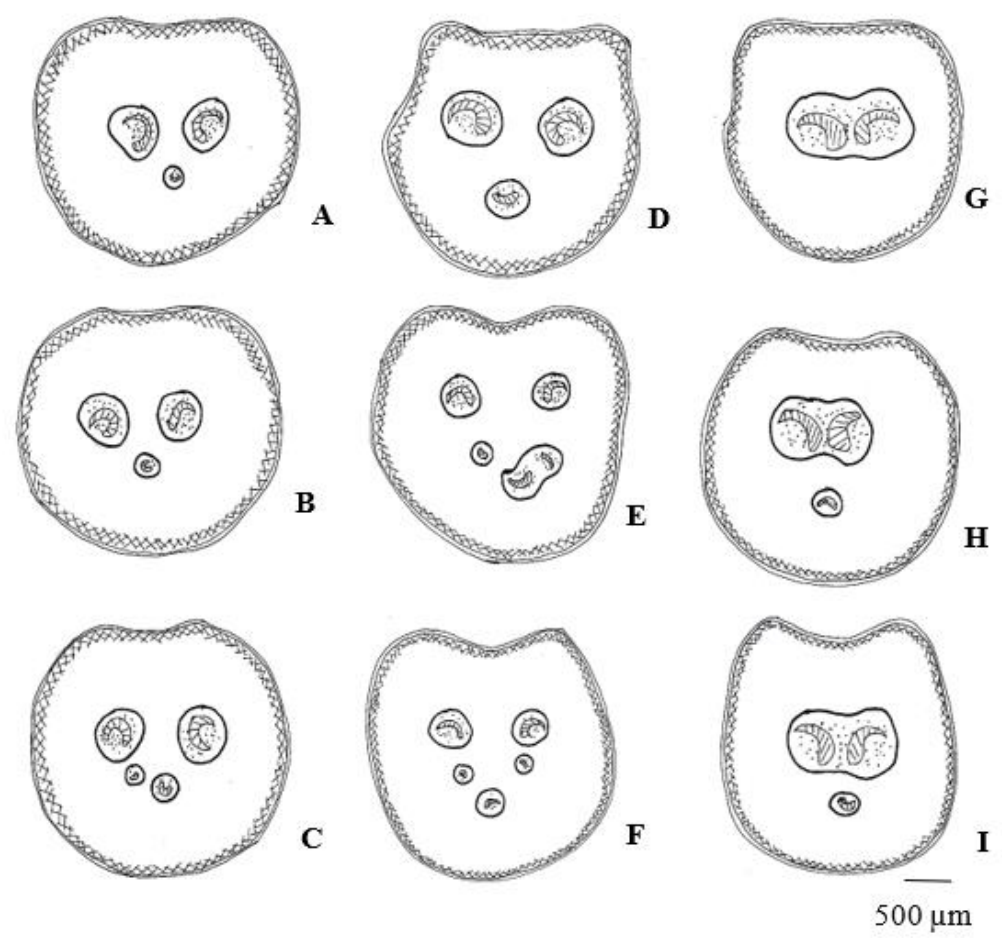

Figure 11. Hand illustrations of the cross-sections of Nephrolepidaceae petiole cross-sections showing the vascular bundle arrangement along the petiole: A, B, C. $N$. cordifolia, D, E, F. N. biserrata; G, H, I. $N$. falcata. Basal section, close to the rhizome. A, D, G. Middle section of petioles. B, E, H. Upper section, near the blade. $\mathbf{C}, \mathbf{F}, \mathbf{I}$. grid $=$ sclerenchyma, thick line $=$ endodermis + pericycle, dotted $=$ phloem, parallel lines $=$ xylem. Bars. A-I $500 \mu \mathrm{m}(40 \mathrm{x})$
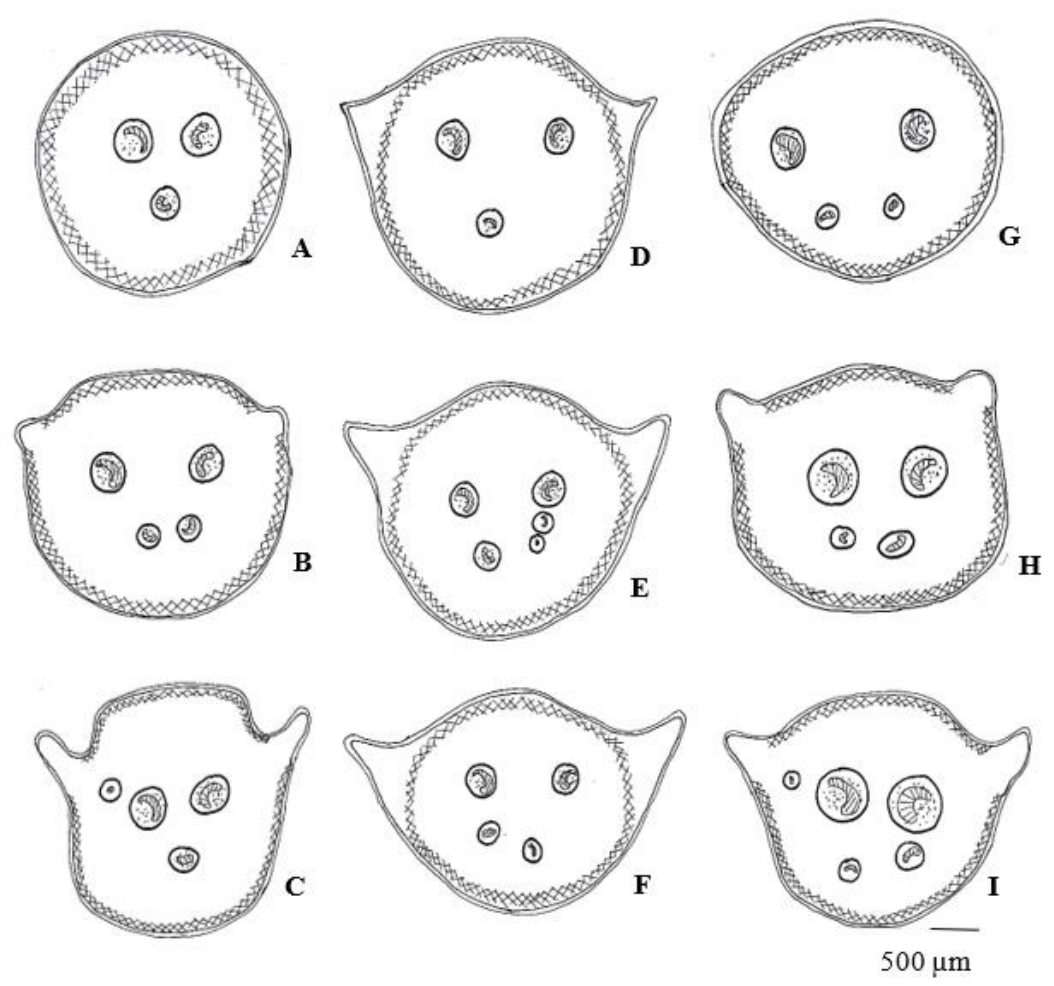

Figure 12. Hand illustrations of the cross-sections of Polypodiaceae petiole cross-sections showing the vascular bundle arrangement along the petiole: A, B, C. Microsorum heterocarpum, D, E, F. Microsorum punctatum; G, H, I. Phymatosorus scolopendria. Basal section, close to the rhizome. A, D, G. Middle section of petioles. B, E, H. Upper section, near the blade. C, F, I. grid = sclerenchyma, thick line $=$ endodermis + pericycle, dotted $=$ phloem, parallel lines $=$ xylem. Bars. A-I $500 \mu \mathrm{m}(40 \mathrm{x})$ 


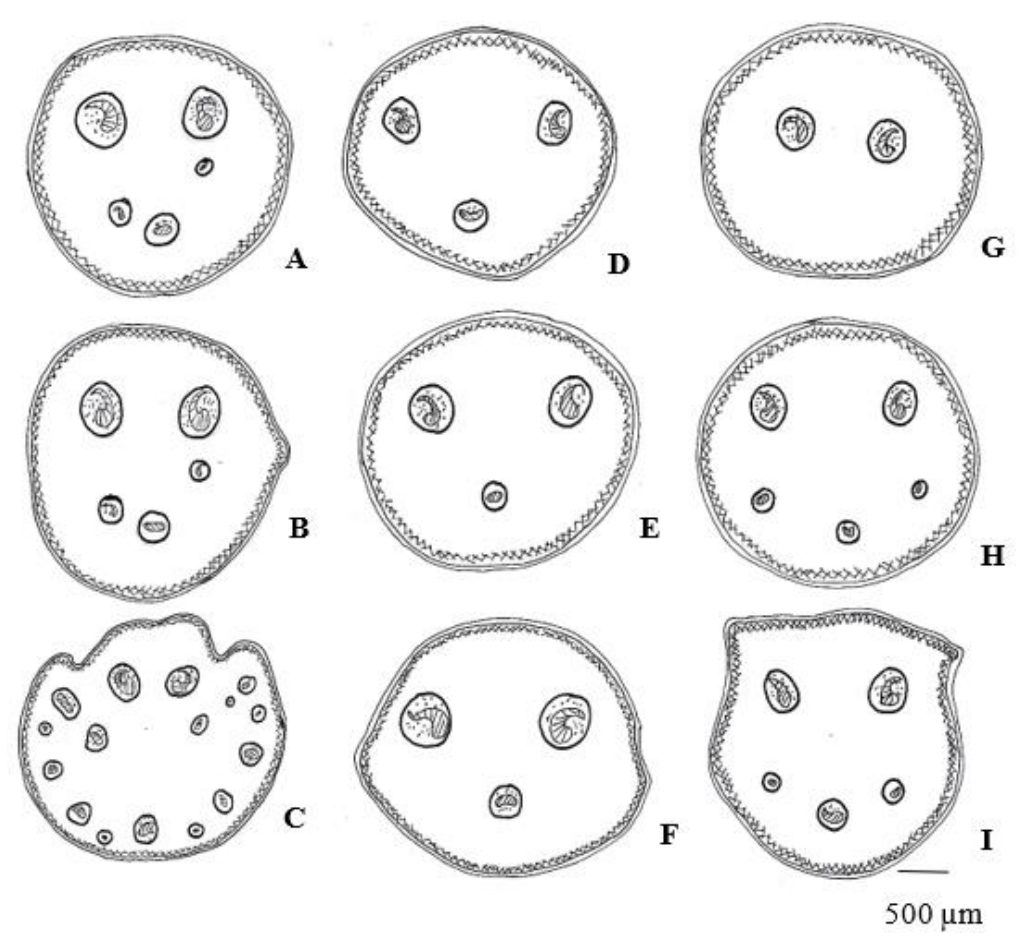

Figure 13. Hand illustrations of the cross-sections of Tectariaceae petiole cross-sections showing the vascular bundle arrangement along the petiole: A, B, C. T. angulata, D, E, F. T. dissecta; G, H, I. T. hilocarpa. Basal section, close to the rhizome. A, D, G. Middle section of petioles. B, E, H. Upper section, near the blade. C, F, I. grid = sclerenchyma, thick line $=$ endodermis + pericycle, dotted $=$ phloem, parallel lines $=$ xylem. Bars. A-I $500 \mu \mathrm{m}(40 \mathrm{x})$

\section{Construction of dichotomous key to families of Eupolypods I using petiole anatomical characters}

An attempt was made to construct a dichotomous key using petiole anatomical characters to the species level, however, it was impossible due to few character states. Key to the genus level was also tried but not successful. Available petiole anatomical characters can be used to construct a dichotomous key only up to the family level. Hence, it can be concluded that petiole anatomical characters can only key eupolypods I up to the family level. There is a need to incorporate other anatomical character states (stoma, trichomes, cell size, etc.) to successfully key out eupolypods I to generic or perhaps species level. Other vegetative and reproductive characters such as leaf shape, size, margins, spore structure, antheridium, and archegonium characters and many more have been used by Copeland (1958), Price (1975), and Amoroso (1993). The main highlight of this research outcome is that, petiole anatomy characters themselves cannot separate eupolypods I to the species level. However, in combination with other characters, this is possible. Petiole anatomy characters is mainly supplementary in cases where construction of dichotomous key is concerned.

Key to the nine families of eupolypods I using petiole anatomy characters

1. Circumendodermal band absent

2. Two vascular bundles (VB)

2. Three vascular bundles (VB)

3. Semi-circle shaped VB

3. U-shaped VB Hypodematiaceae

Didymochlaenaceae Dryopteridaceae

1. Circumendodermal band present

4. Protostele pattern Davalliaceae

4. Dictyostele pattern

5. S-shaped xylem Lomariopsidaceae

5. Hook-shaped xylem Tectariaceae

6. C-shaped xylem 7. 3 to $5 \mathrm{VB}, \mathrm{V}$-shaped VB

7. 3 to $4 \mathrm{VB}, \mathrm{U}$-shaped VB Nephrolepidaceae

6. Arc-shaped xylem Polypodiaceae Oleandraceae 
In summary, the number and shape of vascular bundles, the shape of xylem strand, presence and absence of adaxial grooves, and the presence and absence of $\mathrm{CB}$ were the taxonomically significant characters of eupolypods I species. These are useful characters, especially to those morphologically similar specimens. Incidentally, using a dichotomous key, petiole anatomy characters, can only be used at the family level. Applying it at the generic and species level requires combination of other morphoanatomical character states. Indeed, petiole anatomical characters can delimit at the family level.

\section{ACKNOWLEDGEMENTS}

We would like to express our appreciation to the Department of Science and Technology-Accelerated Science and Technology Human Resource Development Program, (DOST-ASTHRDP) for the financial support in the conduct of the study. Furthermore, we would like to extend our thanks to the University of the Philippines Los Baños for granting us permission to collect in Mt. Makiling Forest Reserve and Quezon-Laguna UP Land Grant. Also, a special thanks to-Assoc.Prof. Pastor Malabrigo of the University of the Philippines Los Baños for allowing us to join in their fieldwork in Mt. Mantalingahan, Palawan with a gratuitous permit no. 2019-25.

\section{REFERENCES}

Amoroso VB. 1993. Ferns of the Philippines. Central Mindanao University, Musuan, Bukidnon.

Beck CB. 2010. An Introduction to Plant Structure and Development: Plant Anatomy for the Twenty-First Century. Cambridge University Press, Cambridge.

Berlyn GP, Mikshe JP. 1976. Botanical Microtechnique and Cytochemistry. Iowa State Univ. Press, Iowa.

Chamberlain CJ. 1932. Methods in Plant Histology. The University of Chicago Press, Chicago.

Ching RC. 1963. A reclassification of the family Thelypteridaceae from the mainland of Asia. Acta Phytotaxonomica Sinica 8: 289-335.

Christenhusz M, Chase M. 2014. Trends and concepts in fern classifcation. Ann Bot 113 (4): 571-594.

Copeland EB. 1958. Fern Flora of the Philippines. Bureau of Printing, Manila.

Evert R. 2006. Esau's Plant Anatomy, Meristems, Cells, and Tissues of the Plant Body: Their Structure, Function, and Development. 3rd ed. John Wiley \& Sons, Inc., Hoboken, NJ.

Hacke UG, Sperry JS. 2001. Functional and ecological xylem anatomy. Perspectives in plant ecology, evolution and systematics 4 (2): $97-115$.

Hernandez-Hernandez V, Terrazas T, Mehltreter K, Angeles G. 2012 Studies of petiolar anatomy in ferns: structural diversity and systematic significance of the circumendodermal band. Bot J Linn Soc 169 (4): 596-610.
Hernandez-Hernandez V, Terrazas T, Stevenson DW. 2009. Ontogeny of Ctenitis melanosticta (Kunze) Copel. and Diplazium expansum Willd. (Dryopteridaceae) fronds with emphasis on the circumendodermal sheath. Feddes Repertorium 120 (7-8): 426-442.

Hovenkamp PH. 1998. Polypodiaceae. In: Kalkman C. et al. (eds.). Flora Malesiana, Series II, Ferns and Fern Allies, Volume 3, Rijksherbarium/Hortus Botanicus, Leiden.

Johansen DA. 1940. Plant Microtechnique. McGraw Hill, NewYork.

Kato M, Mitsuta S. 1980. Stelar organization in davallioid ferns. Phytomorphology 29: 362-369.

Kramer KU. 1990. Pteridophytes and Gymnosperms. The Families and Genera of Vascular Plants, vol 1. Springer, Berlin.

Kuo LY, Li FW, Chiou WL, Wang CN. 2011. First insights into fern Matk phylogeny. Mol Phylogenet Evol 59: 556-566.

Lehtonen S. 2011. Towards resolving the complete fern tree of life. PLoS ONE 6: e24851. DOI: 10.1371/journal.pone.0024851.

Lin BL, Devol CE. 1977. The use of stipe characters in fern taxonomy I. Taiwania 22 (1): 91-99.

Liu HM, Jiang RH, Guo J, Hovenkamp P, Perrie LR, Shepherd L, Hennequin S, Schneider H. 2013. Towards a phylogenetic classification of the climbing fern Genus Arthropteris. Taxon 62: 688700 .

Martinez OG, Vilte I. 2012. The structure of petioles in Pteris (Pteridaceae). Am Fern J 102 (1): 1-11.

Noraini T, Amirul-Aiman AJ, Jaman R, Nor-Fairuz AR, Maideen H, Damanhuri A, Ruzi A. 2014. Systematic significance of stipe anatomy in Peninsular Malaysian Blechnum L. (Blechnaceae) species. Malays Appl Biol J 43 (2): 119-125.

Noraini T, Ruzi AR, Nadiah N, Nisa RN, Maideen H, Solihani SN. 2012. Stipe anatomical characteristics in some Davallia (Davalliaceae) Species in Malaysia. Sains Malaysiana 41 (1): 53-62.

Ogura Y. 1972. Comparative Anatomy of Vegetative Organs of the Pteridophytes. Gebrüder Borntraeger, Berlin

Patil SM, Kachhiyapatel RN, Rajput KS. 2019. Review on the genus Tectaria Cav. from India. Plant Sci Today 6 (2): 170-182.

PPG I. 2016. A community-derived classification for extant lycophytes and ferns. J Syst Evol 54 (6): 563-603.

Price M. 1975. Pteridophytes of Mt. Makiling and Vicinity. [Thesis]. University of the Philippines, Los Banos.

Regalado L, Schmidt AR, Krings M, Bechteler J, Schneider H, Heinrichs J. 2018. Fossil evidence of eupolypod ferns in the Mid-Cretaceous of Myanmar. Plant Syst Evol 304 (1): 1-13.

Russow E. 1872. Comparative studies on the histology (histiography and histogeny) of the vegetative and spore-forming organs and the development of the spores of the vascular cryptogams: with consideration of the histology of the phanerogams, starting from the consideration of the marsiliaceen. Commissionnaires de l'Académie Impériale des sciences, France.

Schuettpelz E, Pryer KM. 2007. Fern phylogeny inferred from 400 leptosporangiate species and three plastid genes. Taxon 56 (4): 1037 1050 .

Sen T, Sen U, Holttum RE. 1972. Morphology and Anatomy of the Genera Davallia, Araiostegia and Davallodes, With a Discussion on their Affinities. Kew Bull 27 (2): 217-243.

Stockey R, Nishida H, Rothwell G. 1999. Permineralized ferns from the Middle Eocene Princeton Chert. I. Makotopteris princetonensis Gen. et sp. nov. (Athyriaceae). Intl J Plant Sci 160 (5): 1047-1055.

Testo W, Sundue M. 2016. A 4000-species dataset provides new insight into the evolution of ferns. Mol Phylogenet Evol 105: 200-211.

Tryon RM, Tryon AF. 1982. Ferns and Allied Plants, With Special Reference To Tropical America. Springer, New York.

Wang R, Shao W, Liu L. 2014. Cytotaxonomic study of Hypodematium (Hypodematiaceae) from China. Phytotaxa 161 (2): 101-110. 